\title{
Analysis of the trade relations between the Republic of North Macedonia and Great Britain
}

ISSN $1857-9973$

UDC 339.56:303.725.3(497.7:410)"2009/2019"

\section{Emilija Miteva-Kacarski ${ }^{1}$, Kostadinka Panova², Vesna Georgieva Svrtinov ${ }^{3}$}

${ }^{1}$ Goce Delcev University, Faculty of Economics, Krste Misirkov 10-A, Stip 1200, Republic of North Macedonia, emilija.miteva@ugd.edu.mk

${ }^{2}$ Goce Delcev University, Krste Misirkov 10-A, Stip 1200, Republic of North Macedonia, kostadinka.cabuleva@ugd.edu.mk

${ }^{3}$ Goce Delcev University, Krste Misirkov 10-A, Stip 1200, Republic of North Macedonia, vesna.svrtinov@ugd.edu.mk

\begin{abstract}
This paper's goal is to identify the sectors in which the Republic of North Macedonia has a comparative advantage in terms of its trade relations with Great Britain. Both Revealed Comparative Advantage and Revealed Symmetric Comparative Advantage methodologies had been used in the empirical analysis made during the time period of 2009-2019. The results of the analysis point to the fact that the Republic of North Macedonia had a continuous comparative advantage in the category of miscellaneous manufactured articles in the course of the analysed period, which was mainly resulting from the export of clothes and other linen things, and it was also present in the category of crude materials, except fuel owing to the export of metal ore including metal-containing residues. In 2010, it was evidenced a comparative advantage in the category of chemical products. According to Hinloopen and Marrewijk classifications, the calculated comparative advantage of the Macedonian export in the British market varies from weak to moderate whereas, in the course of two time periods (2010 and 2013), it was evidenced a strong comparative advantage in the category of crude materials, except fuel.
\end{abstract}

Keywords

Competitiveness, Revealed comparative advantage, Trade.

\section{Introduction}

Great Britain is an important trading partner of the Republic of North Macedonia, and it is one of the countries with which our state has a considerable trading volume. The increased volume of trade (above all, in terms of import) between the Republic of North Macedonia and Great Britain is owing to the presence of the British company "Johnson Matthey" which produces catalysts and is located in TIDZ Skopje 1. "Johnson Matthey" is the biggest company in this country regarding both domestic and foreign companies. Moreover, at the 
same time, it is the largest exporter in the Republic of North Macedonia because it sells a quarter of everything that our country exports to foreign markets. Since 2001, Macedonia's foreign trade with Great Britain has been carried out in accordance with the Stabilisation and Association Agreement between the Republic of North Macedonia and the European Union up till now. Due to Great Britain's official abandonment of the European Union on 29 March 2020 , it is being worked on a new version of the bilateral agreement on the partnership, trading, and cooperation between Macedonia and the United Kingdom, which will renew the current Stabilisation and Association Agreement among the EU and the Republic of North Macedonia by using the two-year transition period in the course of which the trade will keep on developing without any tariffs as before.

The indirect risks resulting from Great Britain's exit from the European Union, which would have an impact on the Macedonian economy, will undeniably depend on the effects they have upon the European Union as our most important trading partner. The potential direct effects on the minor relation between our domestic economy and Britain's one are considered to be insignificant. The domestic economic activity could be made potentially sensitive to the ongoing events in Britain's economy through a few direct channels after the Brexit. What is most important for a small and open economy is the trade channel, i.e., the exchange of goods with British companies. The direct exposure to Britain's economy's happenings can be noticed in the direct investments and the exchange rate's fluctuations. The British investors' direct capital outlays' state regarding the domestic economy presents a very small portion when taking into account the total direct investments' state.

The influence stemming out of the British pound's value change is also regarded as insignificant considering its small share in certain main economic categories. The gross external debt estimated in British pounds is very small i.e., negligible referring to the insignificant risk of the British pound's last fluctuations. At the same time, the British pound's share within the deposits' and credits' currency structure of the domestic baking system's balance sheets is irrelevant. Therefore, the risk of bigger changes in this currency's value is minimal. The risk of transmitting the worsened economic situation from Britain through financial channels, mostly through the banking sector, is also considered to be insignificant due to the weak financial connection of both economies. In general, the direct effects of Great Britain's exit from the EU on the Macedonian economy are estimated as small, whereas a potential risk presents the indirect transmission of effects through the EU, which is our most important trading partner.

The aim of this paper is to identify the sectors in which the Republic of North Macedonia has a comparative advantage in terms of its trade relations with Great Britain. The paper is divided into three parts. The first part provides an insight into the relevant literature which uses the concept of comparative advantage both in terms of the Republic of North Macedonia and Great Britain. The second part presents the methodology used for calculating the comparative advantage. The third part makes an analysis of the value, dynamics, and structure of trade exchange between the Republic of North Macedonia and Great Britain, and it presents the results obtained by making empirical analyses of the comparative advantage of the export from the Republic of North Macedonia to Great Britain.

\section{Literature review}

There are different measures for determining the comparative advantage, but the most commonly used measure in relation to various studies is the methodology of Revealed Comparative Advantage (RCA). This methodology was formulated by Leisner, whereas Balassa has been developing it for a further analysis and measurement of the production industries' comparative advantage [1]. Hence, the Balassa Index is very often used for calculating the sectoral specialisation of national economies. On the other hand, David 
Ricardo' theory of comparative advantages, according to which each country or region has to produce and export relatively more in those industries where it is relatively more productive, is a useful tool for making a theoretical, but not an empirical analysis. The Heckscher-Ohlin's theory represents a thesis according to which the international and regional differences related to production costs do not arise from the different level of productivity, but from the difference in terms of provision with separate sectors of production in the given territories [21] .

A study from the Institute of Public Policy Research, a UK based think tank, calculated the UK's RCA using 2012 trade data, and found that the UK has a large competitive advantage in services [4]. Specifically, in insurance, financial, communication and business services (business services include legal, accountancy, management, advertising etc). In goods, the UK has a competitive advantage in pharmaceuticals, aerospace and chemicals. The advantage in goods is smaller than in services. The study also looked at how RCA for these sectors changed between 2002 and 2012 and found that over the past 10 years, the UK improved its competitiveness in the sectors it was already good at (insurance, finance, communication, aerospace, pharmaceuticals etc.) while losing competitiveness (or not gaining much) in other areas. The results of this research are also proved by BIS economics paper no.19, Benchmarking UK Competitiveness in the Global Economy (2012) according to which [4]:

- The UK has the highest RCA in the G7 across the range of financial, commercial and information services as well as pharmaceuticals.

- $\quad$ The UK's RCA is at or above the G7 average in areas such as aerospace, chemicals, food and beverages.

- The UK's RCA is at or below the G7 average across the majority of manufacturing sectors as well as primary product sectors such as agriculture and minerals.

According to OECD (2008), in 2006, the apparel manufacturing sector was the largest export category in the Republic of North Macedonia [12]. The revealed comparative advantage of the Macedonian apparel manufacturing industry in 2007 was 7.3, indicating that the country has a definite advantage in apparel export to the EU, compared with the other Western Balkan economies. The 2007 RCA calculation for the Republic of North Macedonia was the highest in the Western Balkans. The only SITC two-digit level sector in the country with a higher RCA calculation in 2007 was iron and steel. According to OECD (2019), North Macedonia has specialised in relatively complex and exportoriented medium-technology products, mostly thanks to substantial investment flows in the 2010s [14]. These include motor vehicle parts and different types of machinery, such as lifting, food preparation, harvesting and bottling machines. While vehicle components are both exported to Belgium and fed into the GCESC (German-Central European Supply Chain), machinery is exported to the Western Balkans, in particular in Serbia and Albania.

Ramadani and Madzova (2018) measured the RCA for each of Macedonian export lines for the time period 2005-2015 and from the analyses it can be concluded that although the country's main comparative advantages still remain in the traditional exports product lines (textiles, food \& vegetables, footwear, metals and minerals), the radical increase of chemical products have pushed them at the second position in terms of comparative advantages, just behind the textiles product line [16]. Analysing the trend of development of the Reveled Comparative Advantage indexes over the observed ten-year period, it can be concluded that there is a decreased level of comparative advantages at traditional exports products such as "Metals" (with RCA index of 5,17 in 2005 to 1,53 in 2015), "Textiles" (having RCA index of 5,14 in 2005 to 3,14 in 2015), "Food Products" (with RCA index of 4,32 in 2005 to 2,00 in 2015), "Footwear" (with RCA index of 4,11 in 2005 to 1,58 in 2015) and "Vegetables" (RCA index of 1,96 in 2005 to 1,12 in 2015). However, "Minerals" are the only export product line 
that has slightly increased its comparative advantage over the observed period, starting with an index of 2, 17 in 2005 and achieving 2, 28 in 2015.

\section{Methodolgy}

Countries' export potential is predominantly analysed by using RCA measures. There is a probability that the countries with similar RCA profiles do not have an intensive trade exchange on a bilateral level. The results calculated by using the RCA model give useful information for new partnerships and potential trading opportunities. The index of revealed comparative advantage ( $\mathrm{B}$ index) was first formulated by Balassa (1965) [1] :

$$
R C A=\left(\frac{X_{i j}}{X_{n j}}\right) /\left(\frac{X_{i t}}{X_{n t}}\right)
$$

where $X$ is export, $i$ - country index, $j$ - commodity index, $n$ - set of countries, and $t$ - set of commodities.

According to this index, the comparative advantage can be calculated first by comparing a certain product's share in terms of one country's export to the same product's share in the total export of another country or a group of countries, and then by comparing the analysed country's share in terms of its total export to the export of a certain country or a group of countries. If $\mathrm{RCA}>1$, then the country has a comparative advantage in comparison with another country and/or vice versa.

Hinloopen and Marrewijk (2001) classify the power of comparative advantage in four steps: Class a: $\rightarrow 0<\mathrm{RCA} \leq 1$ - No comparative advantage; Class b: $\rightarrow 1<\mathrm{RCA} \leq 2$ - A weak comparative advantage;

Class c: $\rightarrow 2<\mathrm{RCA} \leq 4$ - A moderate comparative advantage; Class $\mathrm{d}: \rightarrow 4<\mathrm{RCA}-\mathrm{A}$ strong comparative advantage [7].

The Balassa Index has been criticized because it does not take into account the different effects of agricultural policies and asymmetrical values. Namely, the trade's structure may be under the influence of different state interventions and trade restrictions. However, the asymmetrical value of the index points to the fact that it varies from one to infinity if the country has a comparative advantage of a certain product, and that it varies between zero and one if the country does not have a comparative advantage, herewith it is estimated the relative validity of a certain sector.

Because of these critiques, it is taken into consideration the Revealed Symmetric Comparative Advantage (RSCA) index, formulated by Dalum et al. (1998) [5]. The RSCA index is calculated in the following way:

$$
R S C A=R C A-1 / R C A+1 \quad(2)
$$

The RSCA values vary between -1 and 1 , herewith the values between 0 and 1 denote the presence of comparative advantage, whereas the values between -1 and 0 denote the nonexistence of comparative advantage.

This paper's objective is to identify the sectors in which the Republic of North Macedonia has a comparative advantage in terms of its export in Great Britain. The Republic of North Macedonia's revealed comparative advantage in relation to Great Britain was calculated for the time period of $2006-2015$ by using the Standard International Trade Classification, Revision 4 (SITC, Revision 4), which classifies goods into 10 groups: 
0 - Food products

1 - Beverages and tobacco

2 - Crude materials, except fuel

3 - Mineral fuels, lubricants, and related materials

4 - Animal and vegetable oils and fats

5 - Chemicals and related products

6 - Manufactured goods classified mainly by material

7 - Machinery and transport equipment

8 - Miscellaneous manufactured articles

9 -Special transaction and commodities not classified according to kind

The data used in the course of the research are official data of the State Statistical Office of the Republic of North Macedonia.

\section{Findings}

The trade exchange between the Republic of North Macedonia and Great Britain in the time period of 2009-2019 is presented in table 1 [18]:

Table 1 Trade exchange between the Republic of North Macedonia and Great Britain in the time period of 2009-2019 (in thousands of dollars)

\begin{tabular}{|l|c|c|c|c|c|c|}
\hline & $\mathbf{2 0 0 9}$ & $\mathbf{2 0 1 0}$ & $\mathbf{2 0 1 1}$ & $\mathbf{2 0 1 2}$ & $\mathbf{2 0 1 3}$ & $\mathbf{2 0 1 4}$ \\
\hline Export & 42917 & 59288 & 54304 & 62928 & 80908 & 68837 \\
\hline Import & 63562 & 285641 & 593064 & 560938 & 726904 & 893212 \\
\hline Total trade & 106479 & 344929 & 647368 & 623866 & 807812 & 962049 \\
\hline $\begin{array}{l}\text { Trade } \\
\text { Surplus/Deficit }\end{array}$ & -20645 & -226353 & -538760 & -498010 & -645996 & -824375 \\
\hline Export/Import ratio & 67,51 & 20,75 & 9,15 & 11,21 & 11,13 & 7,70 \\
\hline & $\mathbf{2 0 1 5}$ & $\mathbf{2 0 1 6}$ & $\mathbf{2 0 1 7}$ & $\mathbf{2 0 1 8}$ & $\mathbf{2 0 1 9}$ & \\
\hline Export & 47124 & 60479 & 79013 & 121321 & 160553 & \\
\hline Import & 620672 & 727482 & 780695 & 863292 & 1084941 & \\
\hline Total trade & 667796 & 787961 & 859708 & 984613 & 1245494 & \\
\hline $\begin{array}{l}\text { Trade } \\
\text { Surplus/Deficit }\end{array}$ & -573548 & -667003 & -701682 & -741971 & -924388 & \\
\hline Export/Import ratio & 7,59 & 8,31 & 10,12 & 14,05 & 14,79 & \\
\hline
\end{tabular}

Source: State Statistical Office of North Macedonia

In accordance with the presented and calculated indicators in Table 1, considering the Republic of North Macedonia's case, it is evident the low import coverage with export, reflecting a continuous trade deficit in Macedonia in the analysed period of time. The largest volume of trade between the Republic of North Macedonia and Great Britain was achieved in 2019 in the amount of 1,245 million American dollars.

The values of the products exported from the Republic of North Macedonia to Great Britain in the time period of 2009-2019 are presented in Table 2.

Table 2 Exports according to SITC sectors, in '000 US \$

\begin{tabular}{|l|c|c|c|c|c|c|}
\hline $\begin{array}{l}\text { Food and live } \\
\text { animals }\end{array}$ & 2009 & 2010 & 2011 & 2012 & 2013 & 2014 \\
\hline
\end{tabular}




\begin{tabular}{|c|c|c|c|c|c|c|}
\hline $\begin{array}{l}\text { Beverages and } \\
\text { tobacco }\end{array}$ & 6 & 6 & 3 & 710 & 73 & 163 \\
\hline $\begin{array}{lr}\text { Crude } & \text { materials, } \\
\text { inedible, } & \text { except } \\
\text { fuels } & \\
\end{array}$ & 6780 & 8762 & 2174 & 12868 & 10372 & 14401 \\
\hline $\begin{array}{lr}\text { Mineral } & \text { fuels, } \\
\text { lubricants } & \text { and } \\
\text { related materials }\end{array}$ & 315 & 328 & 1595 & 3378 & 5607 & 3587 \\
\hline $\begin{array}{ll}\text { Animal } & \text { and } \\
\text { vegetable oils, fats } \\
\text { and waxes }\end{array}$ & - & - & - & - & - & - \\
\hline $\begin{array}{l}\text { Chemicals and } \\
\text { related products, } \\
\text { n.e.s }\end{array}$ & 26 & 14443 & 7652 & 4620 & 5086 & 5237 \\
\hline $\begin{array}{l}\text { Manufactured } \\
\text { goods classified } \\
\text { chiefly by material }\end{array}$ & 12850 & 11184 & 12108 & 6599 & 22556 & 4920 \\
\hline $\begin{array}{l}\text { Machinery and } \\
\text { transport equipment }\end{array}$ & 413 & 806 & 1895 & 2391 & 3945 & 7271 \\
\hline $\begin{array}{l}\text { Miscellaneous } \\
\text { manufactured } \\
\text { articles }\end{array}$ & 21894 & 23403 & 28401 & 31667 & 32182 & 32076 \\
\hline $\begin{array}{l}\text { Commodities and } \\
\text { transactions not } \\
\text { classified elsewhere } \\
\text { in the SITC }\end{array}$ & 34 & 24 & 12 & 4 & 16 & 12 \\
\hline Total & 42917 & 59288 & 54304 & 62928 & 80908 & 68837 \\
\hline & 2015 & 2016 & 2017 & 2018 & 2019 & \\
\hline $\begin{array}{l}\text { Food and live } \\
\text { animals }\end{array}$ & 1350 & 1883 & 3422 & 6039 & 6037 & \\
\hline $\begin{array}{l}\text { Beverages and } \\
\text { tobacco }\end{array}$ & 101 & 63 & 57 & 3227 & 9334 & \\
\hline $\begin{array}{lr}\begin{array}{l}\text { Crude } \\
\text { inedible, }\end{array} & \text { materials, } \\
\text { fuels } & \text { except } \\
\end{array}$ & 8741 & 15417 & 14650 & 17630 & 45968 & \\
\hline $\begin{array}{lr}\text { Mineral } & \text { fuels, } \\
\text { lubricants and } \\
\text { related materials }\end{array}$ & 1868 & 1804 & 2363 & 3850 & 5232 & \\
\hline $\begin{array}{l}\text { Animal } \\
\text { vegetable oils, fats } \\
\text { and waxes }\end{array}$ & 1000 & 100.1 & 2000 & 400 & ULC & \\
\hline $\begin{array}{l}\text { Chemicals and } \\
\text { related products, } \\
\text { n.e.s }\end{array}$ & 2062 & 6780 & 5709 & 14475 & 26401 & \\
\hline $\begin{array}{l}\text { Manufactured } \\
\text { goods classified } \\
\text { chiefly by material }\end{array}$ & 3897 & 3791 & 5202 & 3067 & 4049 & \\
\hline $\begin{array}{l}\text { Machinery and } \\
\text { transport equipment }\end{array}$ & 6669 & 8241 & 10943 & 13122 & 10131 & \\
\hline $\begin{array}{l}\text { Miscellaneous } \\
\text { manufactured } \\
\text { articles }\end{array}$ & 22423 & 22486 & 36629 & 59880 & 53391 & \\
\hline $\begin{array}{l}\text { Commodities and } \\
\text { transactions not } \\
\text { classified elsewhere } \\
\text { in the SITC }\end{array}$ & 9 & 11 & 35 & 28 & 6 & \\
\hline
\end{tabular}


By analysing the export structure of the Republic of North Macedonia in relation to Great Britain, it is concluded that in the period of 2009-2019, it was dominant the export of coloured metals, clothes, and products made of iron and steel. Since 2010 when the company "Johnson Matthey" was opened in the free economic zone Bunardzik, it has been considerably increased the export of catalysts of the bearers of precious metals which belong in the category of chemical products.

The import of products from Great Britain into the Republic of North Macedonia is shown in nominal values in Table 3 [18]:

Table 3 Imports according to SITC sectors, in '000 US \$

\begin{tabular}{|c|c|c|c|c|c|c|}
\hline & 2009 & 2010 & 2011 & 2012 & 2013 & 2014 \\
\hline $\begin{array}{l}\text { Food and live } \\
\text { animals }\end{array}$ & 1777 & 1470 & 2384 & 1939 & 3478 & 4605 \\
\hline $\begin{array}{l}\text { Beverages and } \\
\text { tobacco }\end{array}$ & 2177 & 2082 & 2422 & 2128 & 2820 & 2408 \\
\hline $\begin{array}{l}\text { Crude materials, } \\
\text { inedible, except } \\
\text { fuels }\end{array}$ & 903 & 1481 & 259 & 152 & 254 & 825 \\
\hline $\begin{array}{l}\text { Mineral fuels, } \\
\text { lubricants and } \\
\text { related materials }\end{array}$ & 21 & 85 & 153 & 105 & 108 & 53 \\
\hline $\begin{array}{l}\text { Animal and } \\
\text { vegetable oils, fats } \\
\text { and waxes }\end{array}$ & 18 & 11 & 6 & 5 & 5 & 5 \\
\hline $\begin{array}{l}\text { Chemicals and } \\
\text { related products, } \\
\text { n.e.s }\end{array}$ & 18122 & 126292 & 156488 & 105953 & 152162 & 38410 \\
\hline $\begin{array}{l}\text { Manufactured } \\
\text { goods classified } \\
\text { chiefly by material }\end{array}$ & 9903 & 123634 & 398768 & 423056 & 543372 & 821321 \\
\hline $\begin{array}{l}\text { Machinery and } \\
\text { transport equipment }\end{array}$ & 21507 & 21744 & 25236 & 20641 & 18454 & 20025 \\
\hline $\begin{array}{l}\text { Miscellaneous } \\
\text { manufactured } \\
\text { articles }\end{array}$ & 9132 & 8838 & 7343 & 6865 & 6245 & 5542 \\
\hline $\begin{array}{l}\text { Commodities and } \\
\text { transactions not } \\
\text { classified elsewhere } \\
\text { in the SITC }\end{array}$ & - & 3 & - & 90 & 3 & 15 \\
\hline Total & $\begin{array}{c}63562 \\
2015 \\
\end{array}$ & $\begin{array}{c}285641 \\
2016 \\
\end{array}$ & $\begin{array}{c}593064 \\
2017 \\
\end{array}$ & $\begin{array}{c}560938 \\
2018 \\
\end{array}$ & $\begin{array}{c}726904 \\
2019 \\
\end{array}$ & 893212 \\
\hline $\begin{array}{l}\text { Food and live } \\
\text { animals }\end{array}$ & 4318 & 4344 & 4362 & 5123 & 6657 & \\
\hline $\begin{array}{l}\text { Beverages and } \\
\text { tobacco }\end{array}$ & 2113 & 2515 & 2850 & 2420 & 2420 & \\
\hline $\begin{array}{l}\text { Crude materials, } \\
\text { inedible, except } \\
\text { fuels }\end{array}$ & 582 & 172 & 265 & 177 & 185 & \\
\hline $\begin{array}{l}\text { Mineral fuels, } \\
\text { lubricants and } \\
\text { related materials }\end{array}$ & 26 & 42 & 55 & 65 & 101 & \\
\hline
\end{tabular}




\begin{tabular}{|c|c|c|c|c|c|}
\hline $\begin{array}{l}\text { Animal and } \\
\text { vegetable oils, fats } \\
\text { and waxes }\end{array}$ & - & - & - & - & 2 \\
\hline $\begin{array}{l}\text { Chemicals and } \\
\text { related products, } \\
\text { n.e.s }\end{array}$ & 23592 & 25721 & 31316 & 58457 & 136765 \\
\hline $\begin{array}{l}\text { Manufactured } \\
\text { goods classified } \\
\text { chiefly by material }\end{array}$ & 568837 & 665570 & 712556 & 763509 & 900694 \\
\hline $\begin{array}{l}\text { Machinery and } \\
\text { transport equipment }\end{array}$ & 16051 & 21213 & 21393 & 24439 & 29499 \\
\hline $\begin{array}{l}\text { Miscellaneous } \\
\text { manufactured } \\
\text { articles }\end{array}$ & 5147 & 7714 & 7884 & 9074 & 8608 \\
\hline $\begin{array}{l}\text { Commodities and } \\
\text { transactions not } \\
\text { classified elsewhere } \\
\text { in the SITC }\end{array}$ & & 185 & & 17 & 7 \\
\hline Total & 620672 & 727482 & 780695 & 863292 & 1084941 \\
\hline
\end{tabular}

Source: State Statistical Office of North Macedonia

Dominant categories of products comprising the import structure of the Republic of North Macedonia in relation to Great Britain in the analysed period are the colloidal precious metals, platinum, and platinum alloys which present the basis for the production of catalysts, paints and varnishes based on synthetic polymers, other motor vehicles for the transport of persons, textile fabrics for the needs of process manufacturing in the Macedonian textile factories as well as medicines.

The comparative advantage in the trade exchange between the Republic of North Macedonia and Great Britain is shown in Table 4 [18]:

Table 4 The comparative advantage in the trade exchange between the Republic of North Macedonia and Great Britain

\begin{tabular}{|c|c|c|c|c|c|c|}
\hline & 2009 & 2010 & 2011 & 2012 & 2013 & 2014 \\
\hline $\begin{array}{l}\text { Food and live } \\
\text { animals }\end{array}$ & 0.134 & 0.057 & 0.102 & 0.129 & 0.155 & 0.216 \\
\hline $\begin{array}{l}\text { Beverages and } \\
\text { tobacco }\end{array}$ & 0.002 & 0.002 & 0.001 & 0.191 & 0.014 & 0.053 \\
\hline $\begin{array}{l}\text { Crude materials, } \\
\text { inedible, except } \\
\text { fuels }\end{array}$ & 2.463 & 1.905 & 0.621 & 3.098 & 1.981 & 3.875 \\
\hline $\begin{array}{l}\text { Mineral fuels, } \\
\text { lubricants and } \\
\text { related materials }\end{array}$ & 0.098 & 0.072 & 0.337 & 0.834 & 2.799 & 2.971 \\
\hline $\begin{array}{l}\text { Animal and } \\
\text { vegetable oils, fats } \\
\text { and waxes }\end{array}$ & 0.000 & 0.000 & 0.000 & 0.000 & 0.000 & 0.000 \\
\hline $\begin{array}{l}\text { Chemicals and } \\
\text { related products, } \\
\text { n.e.s }\end{array}$ & 0.010 & 2.138 & 0.845 & 0.433 & 0.322 & 0.358 \\
\hline $\begin{array}{l}\text { Manufactured } \\
\text { goods classified } \\
\text { chiefly by material }\end{array}$ & 1.051 & 0.638 & 0.810 & 0.406 & 1.162 & 0.369 \\
\hline $\begin{array}{l}\text { Machinery and } \\
\text { transport equipment }\end{array}$ & 0.170 & 0.229 & 0.442 & 0.382 & 0.367 & 0.502 \\
\hline
\end{tabular}




\begin{tabular}{|c|c|c|c|c|c|c|}
\hline $\begin{array}{l}\text { Miscellaneous } \\
\text { manufactured } \\
\text { articles }\end{array}$ & 1.854 & 1.843 & 2.800 & 2.593 & 2.072 & 2.514 \\
\hline $\begin{array}{l}\text { Commodities and } \\
\text { transactions not } \\
\text { classified elsewhere } \\
\text { in the SITC }\end{array}$ & 2.573 & 0.575 & 0.361 & 0.261 & 2.626 & 0.205 \\
\hline & 2015 & 2016 & 2017 & 2018 & 2019 & \\
\hline $\begin{array}{l}\text { Food and live } \\
\text { animals }\end{array}$ & 0.383 & 0.433 & 0.708 & 0.915 & 0.658 & \\
\hline $\begin{array}{l}\text { Beverages and } \\
\text { tobacco }\end{array}$ & 0.061 & 0.026 & 0.018 & 0.807 & 1.705 & \\
\hline $\begin{array}{l}\text { Crude materials, } \\
\text { inedible, except } \\
\text { fuels }\end{array}$ & 3.881 & 5.973 & 3.253 & 2.671 & 5.538 & \\
\hline $\begin{array}{l}\text { Mineral fuels, } \\
\text { lubricants and } \\
\text { related materials }\end{array}$ & 2.917 & 2.524 & 1.989 & 1.873 & 1.596 & \\
\hline $\begin{array}{l}\text { Animal and } \\
\text { vegetable oils, fats } \\
\text { and waxes }\end{array}$ & 0.000 & 0.000 & 0.000 & 0.000 & 0.000 & \\
\hline $\begin{array}{l}\text { Chemicals and } \\
\text { related products, } \\
\text { n.e.s }\end{array}$ & 0.194 & 0.475 & 0.302 & 0.494 & 0.677 & \\
\hline $\begin{array}{l}\text { Manufactured } \\
\text { goods classified } \\
\text { chiefly by material }\end{array}$ & 0.467 & 0.440 & 0.489 & 0.181 & 0.190 & \\
\hline $\begin{array}{l}\text { Machinery and } \\
\text { transport equipment }\end{array}$ & 0.573 & 0.485 & 0.471 & 0.340 & 0.192 & \\
\hline $\begin{array}{l}\text { Miscellaneous } \\
\text { manufactured } \\
\text { articles }\end{array}$ & 2.737 & 2.212 & 2.954 & 3.556 & 2.588 & \\
\hline $\begin{array}{l}\text { Commodities and } \\
\text { transactions not } \\
\text { classified elsewhere } \\
\text { in the SITC }\end{array}$ & 0.712 & 0.189 & 0.504 & 0.248 & 0.042 & \\
\hline
\end{tabular}

Source: Author's calculations.

The results presented in Table 4 show the comparative advantage of the Macedonian products on Great Britain's market. Namely, in the analysed period, the comparative advantage was constantly present in the category of miscellaneous manufactured articles owing to the export of clothes and other linen things, as well as in the category of crude materials, except fuel resulting from the export of metal ore including metal-containing residues. In 2010, the comparative advantage was registered in the category of chemical products. According to the classifications of Hinloopen and Marrewijk, the calculated comparative advantage of the Macedonian export to the British market varies from weak to moderate whereas, in the course of two time periods (2010 and 2013), it was evidenced a strong comparative advantage in the category of crude materials, except fuel.

The calculated RSCA index is shown in Table 5:

Table 5 RSCA index

\begin{tabular}{|l|c|c|c|c|c|c|}
\hline & $\mathbf{2 0 0 9}$ & $\mathbf{2 0 1 0}$ & $\mathbf{2 0 1 1}$ & $\mathbf{2 0 1 2}$ & $\mathbf{2 0 1 3}$ & $\mathbf{2 0 1 4}$ \\
\hline $\begin{array}{l}\text { Food and live } \\
\text { animals }\end{array}$ & -0.764 & -0.891 & -0.815 & -0.771 & -0.731 & -0.644 \\
\hline
\end{tabular}




\begin{tabular}{|c|c|c|c|c|c|c|}
\hline $\begin{array}{l}\text { Beverages and } \\
\text { tobacco }\end{array}$ & -0.996 & -0.997 & -0.998 & -0.680 & -0.971 & -0.900 \\
\hline $\begin{array}{lr}\text { Crude } & \text { materials, } \\
\text { inedible, } & \text { except } \\
\text { fuels } & \\
\end{array}$ & 0.422 & 0.312 & -0.233 & 0.512 & 0.329 & 0.590 \\
\hline $\begin{array}{lr}\text { Mineral } & \text { fuels, } \\
\text { lubricants and } \\
\text { related materials }\end{array}$ & -0.822 & -0.866 & -0.496 & -0.091 & 0.474 & 0.496 \\
\hline $\begin{array}{ll}\text { Animal } & \text { and } \\
\text { vegetable oils, fats } \\
\text { and waxes }\end{array}$ & -1.000 & -1.000 & -1.000 & -1.000 & -1.000 & -1.000 \\
\hline $\begin{array}{l}\text { Chemicals and } \\
\text { related products, } \\
\text { n.e.s }\end{array}$ & -0.981 & 0.363 & -0.084 & -0.396 & -0.512 & -0.472 \\
\hline $\begin{array}{l}\text { Manufactured } \\
\text { goods classified } \\
\text { chiefly by material }\end{array}$ & 0.025 & -0.221 & -0.105 & -0.423 & 0.075 & -0.461 \\
\hline $\begin{array}{l}\text { Machinery and } \\
\text { transport equipment }\end{array}$ & -0.709 & -0.627 & -0.387 & -0.447 & -0.463 & -0.331 \\
\hline $\begin{array}{l}\text { Miscellaneous } \\
\text { manufactured } \\
\text { articles }\end{array}$ & 0.299 & 0.297 & 0.474 & 0.443 & 0.349 & 0.431 \\
\hline $\begin{array}{l}\text { Commodities and } \\
\text { transactions not } \\
\text { classified elsewhere } \\
\text { in the SITC }\end{array}$ & 0.440 & -0.270 & -0.470 & -0.586 & -0.585 & -0.660 \\
\hline & 2015 & 2016 & 2017 & 2018 & 2019 & \\
\hline $\begin{array}{ll}\text { Food and live } \\
\text { animals }\end{array}$ & -0.447 & -0.396 & -0.171 & -0.044 & -0.207 & \\
\hline $\begin{array}{ll}\text { Beverages and } \\
\text { tobacco }\end{array}$ & -0.886 & -0.950 & -0.964 & -0.107 & 0.261 & \\
\hline $\begin{array}{lr}\begin{array}{l}\text { Crude } \\
\text { inedible, }\end{array} \\
\text { fuels }\end{array}$ & 0.590 & 0.713 & 0.530 & 0.455 & 0.694 & \\
\hline $\begin{array}{lr}\text { Mineral } & \text { fuels, } \\
\text { lubricants } & \text { and } \\
\text { related materials }\end{array}$ & 0.489 & 0.433 & 0.331 & 0.304 & 0.230 & \\
\hline $\begin{array}{l}\text { Animal } \\
\text { vegetable oils, fats } \\
\text { and waxes }\end{array}$ & -1.000 & -1.000 & -1.000 & -1.000 & -1.000 & \\
\hline $\begin{array}{l}\text { Chemicals and } \\
\text { related products, } \\
\text { n.e.s }\end{array}$ & -0.675 & -0.356 & -0.536 & -0.339 & -0.193 & \\
\hline $\begin{array}{l}\text { Manufactured } \\
\text { goods classified } \\
\text { chiefly by material }\end{array}$ & -0.363 & -0.389 & -0.344 & -0.694 & -0.681 & \\
\hline $\begin{array}{l}\text { Machinery and } \\
\text { transport equipment }\end{array}$ & -0.271 & -0.347 & -0.360 & -0.493 & -0.678 & \\
\hline $\begin{array}{l}\text { Miscellaneous } \\
\text { manufactured } \\
\text { articles }\end{array}$ & 0.465 & 0.377 & 0.494 & 0.561 & 0.443 & \\
\hline $\begin{array}{l}\text { Commodities and } \\
\text { transactions not } \\
\text { classified elsewhere } \\
\text { in the SITC }\end{array}$ & -0.168 & -0.683 & -0.330 & -0.602 & -0.919 & \\
\hline
\end{tabular}

Source: Author's calculations. 
The results of this index vary from -1 to +1 . The calculated results confirm the already established state of the comparative advantage of the Macedonian export to the British market through the application of the RCA index.

\section{Conclusion}

The analysis of the value, dynamics, and structure of trade between the Republic of North Macedonia and Great Britain points to the fact that there was a continuous trade deficit in Macedonia in the time period of 2009-2019. More important product categories which are dominant in the structure of the Republic of North Macedonia's export to the Britain's market are coloured metals, clothes, and products made of iron and steel. Since 2010 when the company "Johnson Matthey" was opened in the free economic zone Bunardzik, it has been significantly increased the export of catalysts of the bearers of precious metals which are classified in the category of chemical products. Given the import, dominant product categories comprising the import structure of the Republic of North Macedonia in relation to Great Britain in the analysed period are the colloidal precious metals, platinum, and platinum alloys being the basis for the catalysts' production, paints and varnishes based on synthetic polymers, other motor vehicles for the transport of persons, textile fabrics for the process manufacturing needs in the Macedonian textile factories as well as medicines.

By applying the RCA and RSCA methodology, it can be stated in terms of the Republic of North Macedonia that in the analysed period, the comparative advantage of Macedonia's export to the Britain's market was continuously present in the category of miscellaneous manufactured articles due to the export of clothes and other linen things, as well as in the category of crude materials, except fuel resulting from the export of metal ore including metal-containing residues. In 2010, it was evidenced a comparative advantage in the category of chemical products. According to Hinloopen and Marrewijk classifications, the calculated comparative advantage of the Macedonian export to the British market ranges from weak to moderate limits whereas, in the course of two time periods (2010 and 2013), it was registered a strong comparative advantage in the category of crude materials, except fuel.

Regarding the trade implications of BREXIT, the trade between the Republic of North Macedonia and Great Britain was regulated according to the Stabilisation and Association Agreement in the course of the eleven-month transition period. On 3 December 2020, right after the exit of Great Britain from the European Union, it was signed an Agreement on partnership, trading, and cooperation used for regulating the trade relations between the Republic of North Macedonia and Great Britain. By signing this Agreement, it was ensured continuity of the trade relations between these two countries after the formal and institutional abandonment of the EU by Great Britain, which has exceptional importance for our economy if it is taken into consideration the fact that over the past 10 years, it has been one of the most important trading partners of our country. Additionally, it is also among the tenth export and import destinations. The preference conditions for trade exchange provided by this Agreement will make it possible for the economic subjects of both countries to keep on trading. Moreover, it will also assist in protecting the economic stability and prosperity of the Republic of North Macedonia, which is particularly important for recovering the economy affected by the COVID-crisis. The agreement provides a framework for even closer political dialogue and more intensive cooperation on important issues such as the environment, education, and human rights. 


\section{REFERENCES}

1. Balassa, B. (1965). Trade liberalisation and "revealed" comparative advantage. The manchester school, 33(2), pp. 99-123.

2. Balassa, B. (1977). Revealed Comparative Advantage Revisited: an Analysis of relative Export Shares of the Industrial Countries, 1953-1971. The Manchester School of Economics and Social Studies 45(2), pp. 327-344.

3. Bellora, C., Emlinger, C., Fouré, J. \& Guimbard, H. (2017), Research for AGRI Committee, EU UK agricultural trade: state of play and possible impacts of Brexit, European Parliament, Policy Department for Structural and Cohesion Policies, Brussels [Online]. Available from: EU - UK agricultural trade: state of play and possible impacts of Brexit (europa.eu) [Accessed: 5 January 2021]

4. BIS (2012) Benchmarking UK Competitiveness in the Global Economy, BIS Economics Paper No. 19 [Online]. Available from: Benchmarking UK Competitiveness in the Global Economy (publishing.service.gov.uk) [Accessed: 5 January 2021]

5. Dalum, B., Laursen, K., \& Villumsen, G. (1998). Structural change in OECD export specialisation patterns: de-specialisation and 'stickiness'. International Review of Applied Economics, 12(3), 423443.

6. Gupta, R. (2015). "FYR Macedonia: Supplier Development Program Analytical Note, Ascending the Global Value Chain by Developing Linkages among Small and Medium-Sized Enterprises (SMEs) and Multinational Corporations (MNCs)." Washington, DC: World Bank.

7. Hinloopen, J., \& Van Marrewijk, C. (2001). On the empirical distribution of the Balassa index. Weltwirtschaftliches Archiv, 137(1), 1-35.

8. IMF (2015). Former Yugoslav Republic of Macedonia. Selected issues. [Online]. Available from https://www.imf.org/external/pubs/ft/scr/2015/cr15243.pdf [Accessed: 12 December 2020]

9. Kostoska, O. (2010). Revealed comparative advantage and competitiveness of the Macedonian economy. International Conference "The Economy and Business in Post-Recession". University "St. Kliment Ohridski" - Bitola, Faculty of Economics - Prilep, Prilep, Macedonia.

10. Kowalski, P. (2011). Comparative advantage and trade performance: Policy implications (No. 121). Paris: OECD Publishing.

11. Liesner, H. H. (1958). The European common market and British industry. The Economic Journal, 68(270), pp. 302-316.

12. OECD. Publishing. (2008). Defining and Strengthening Sector Specific Sources of Competitiveness in the Western Balkans. [Online]. Available from https://wbcrti.info/object/document/7699 [Accessed: 10 May 2020]

13. OECD. Publishing. (2009). Sector specific sources of competitiveness in the Western Balkans: recommendation for a regional investment strategy. [Online]. Available from https://books.google. $\mathrm{mk} /$ books?id=rEpBBIZpBQMC\&pg=PA83\&lpg=PA83\&dq=revealed+comparat ive+advantage+of+the+Republic+of+Macedonia\&source=bl\&ots=a5FSAhEiX\&sig=k0DfLyyuylJ 72lmgyymaOD7gUA\&hl=mk\&sa=X\&ved=2ahUKEwjogPkjZfcAhXrJJoKHWZUBoYQ6AEwEXoECAkQAQ\#v=onepage\&q=revealed\%20comparative\%20ad vantage\%20of\%20the\%20Republic\%200f\%20Macedonia\&f=false [Accessed: 20 December 2020]

14. OECD. Publishing. (2019). Unleashing the Transformation Potential for Growth in the Western Balkans. [Online]. Available from http://www.oecd.org/south-easteurope/programme/Unleashing the Transformation potential for Growth in WB.pdf [Accessed: 20 December 2020]

15. Porter, M. E. (1998). The Competitive Advantage of Nations. Free Press New York.

16. Ramadani, N. \& Madzova, V., "Trends and Challenges of Export Performance in The Republic of Macedonia" (2018). UBT International Conference, 2018, pp.11-125.

17. Springford, J., \& Tilford, S. (2014). The Great British trade-off: The impact of leaving the EU on the UK's trade and investment. Centre for European Reform. [Online]. Available from http://www.cer.eu/sites/default/files/publications/attachments/pdf/2014/pb britishtrade 16jan148285.pdf [Accessed: 17 February 2021]

18. State Statistical Office of North Macedonia http://makstat.stat.gov.mk/PXWeb/pxweb/mk/MakStat/MakStat NadvoresnaTrgovija DetalniPo d DetKumSMTK/150 SMTK ZEMJI ml.px/?rxid=46ee0f64-2992-4b45-a2d9-cb4e5f7ec5ef [Accessed: 17 February 2021] 
19. The World Bank Group. (2017). Positioning FYR Macedonia for the global economy: the impact of reforms and investment promotion in the automotive components manufacturing [Online]. Available from https://openknowledge.worldbank.org/bitstream/handle/10986/29427/123752.pdf?sequence=4\&is Allowed $=y$ [Accessed: 1 February 2021]

20. Vollrath, T. L. (1991.) 'A theoretical evaluation of alternative trade intensity measures of revealed comparative advantage.' Weltwirtschaftliches Archiv 127(2), pp. 265-80.

21. Yeats, A. (1985). 'On the Appropriate Interpretation of the Revealed Comparative Advantage Index: Implications of a Methodology Based on Industry Sector Analysis.' Weltwirtschaftliches Archiv 121 (1), pp. 61-73. 